\title{
The role of protein in the sexual behaviour of males of Ceratitis capitata (Diptera: Tephritidae): mating success, copula duration and number of copulations
}

\author{
lara Sordi Joachim-Bravo; Cyntia Santiago Anjos \& Anne Moreira Costa
}

\begin{abstract}
Departamento de Biologia Geral, Instituto de Biologia, Universidade Federal da Bahia. Rua Barão do Geremoabo, Campus Universitário de Ondina, 40170-290 Salvador, Bahia, Brasil. E-mail: ibravo@ufba.br
\end{abstract}

\begin{abstract}
In this paper, we investigated the influence of protein ingestion during the early adult phase on the sexual behavior of males of Ceratitis capitata (Wiedemann, 1824). The following parameters were evaluated: mating success (ability to be chosen by females), number of copulations, and copula duration. Experiments were carried out using a fifteen-year old laboratory lineage with the occasional introduction of wild flies. Two groups of adult males fed a highprotein diet during their larval phase were given either a high-protein diet (based on Brewer's yeast, concentration $=6.5$ $\mathrm{g} / 100 \mathrm{ml}$ ) or a no-protein diet. Both groups of males were exposed to females fed either a high-protein diet or a noprotein diet and were subsequently evaluated for the parameters listed above. All experiments were conducted at $25^{\circ} \mathrm{C}$, 70\% R.H. and with a photoperiod of L12:D12. The number of copulations was the only parameter affected by adult diet. Males fed a high-protein diet and exposed to females fed a no-protein diet had a greater number of copulations compared with males fed a no-protein diet.
\end{abstract}

KEY WORDS. Fruit flies; insects; nutrition; sexual selection.

Organisms need a variety of nutrients to complete their life-cycle. Amongst these, proteins stand out as being able to influence several different processes such as development, maintenance and reproduction (SLANSKY \& SCRIBER 1985). Previous research on the role of proteins has been conducted on Ceratitis capitata (Wiedemann, 1824), an important pest of fruits worldwide (MaLAVASI et al. 2000). Experiments with this fly revealed that protein deficiency during the larval phase causes delay to complete this life stage, reduction in adult emergence (CAngussu \& Zucoloto 1997, Plácido-Silva et al. 2005), reduction in the size of the adult female and impaired ability to produce eggs (CANGussu \& ZuCOLOTO 1993, 1995). Additionally, tests conducted with laboratory populations showed that ingestion of proteins in the adult phase prologues longevity (PLÁcIDoSilva et al. 2006) and that protein deficiency negatively impacts egg production (CANGUSSU \& ZuCOLOTO 1997). Furthermore, protein consumption in the beginning of the adult stage is positively correlated with various aspects of the sexual behavior of wild and laboratory males, as for example participation in leks, rate of copulation and rate of female insemination (PAPADOPOULOS et al. 1998, Taylor \& Yuval 1999, Shelly et al. 2002).

The lekking behavior of $C$. capitata is a well-known phenomenon (Arita \& Kaneshiro 1989, Hendrichs \& Hendrichs 1990, WhitTiER et al. 1992). A lek is a gathering of males that delimit their territory and exude pheromones to attract females (Féron 1962, Prokopy \& Hendrichs 1979, Arita \& Kaneshiro 1989). Females discriminate between males in the lek, rejecting most advances and copulating only with the male they perceive as best fit (WhitTiER et al. 1992, 1994). Because mating success in this system is a function of female choice, it is believed that sexual selection is a determining factor in the evolution of male characteristics and male mating systems (WHITTIER et al. 1992, 1994, Norry et al. 1999).

Male reproductive success in C. capitata has been shown to correlate with different factors such as nutrition (see review in Yuval et al. 2007), body size (Churchill-STANLAND et al. 1986, Orozco \& Lopez 1993, Rodriguero et al. 2002) and copula duration. However, the lack of a general consensus on the subject and the fact that $C$. capitata is reared in massive quantities for the Sterile Insect Technique (SIT), a method of biological control (KNIPLING 1955), make new research in this area particularly relevant. With respect to the effects of a protein-rich diet in the adult phase on the reproductive success of $C$. capitata, a brief list of the main publications (Tab. I) brings about the main controversies and relevant facts.

The goal of the present study was to compare the reproductive success of males of $C$. capitata fed a protein-rich diet against the reproductive success of males fed a diet without proteins, in the beginning of the adult phase. Three main questions were asked: 1) Do males fed on a protein diet have a higher mating success than males deprived of protein? 2) Do males fed on a protein diet copulate for longer periods of time than males deprived of protein? 3) Do males fed on a protein diet copulate more than males deprived of protein? 


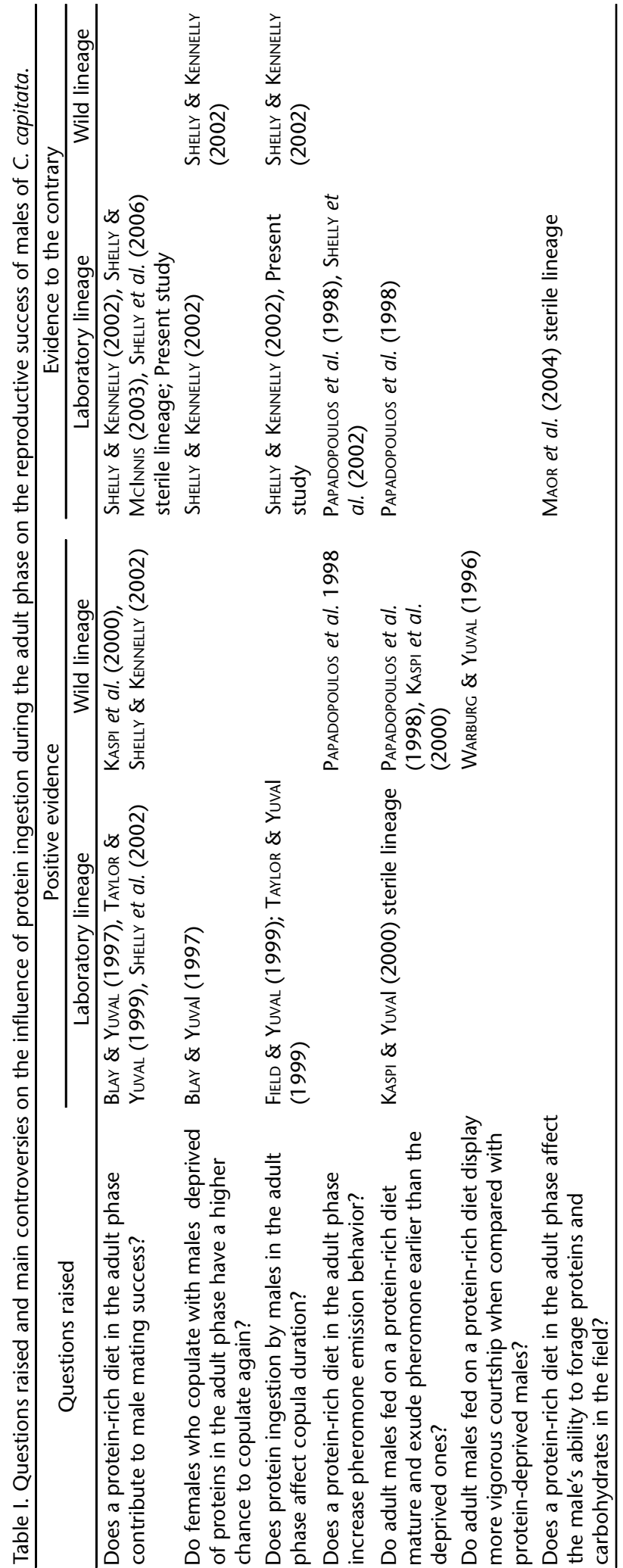

\section{MATERIAL AND METHODS}

The flies used in this study came from a population of $C$. capitata frequently supplied with wild specimens since 1997, and maintained in the Laboratory of Nutritional Ecology, Instituto de Biologia, Universidade Federal da Bahia. Population maintenance followed Zucoloto (1987). Immature were fed a diet of soy flour and Brewer's yeast (CARVALHo et al. 1998).

Two diets were used in the experiments. The first diet contained Brewer's yeast as a source of protein (concentration $=6.5$ g per $100 \mathrm{ml}$ ) and was named " $\mathrm{P} / \mathrm{P}$ " (protein present). This yeast concentration had been previously established as adequate for larvae and adults of $C$. capitata (PLÁCIDo et al. 2006). The second diet contained no protein and was named "P/A" (protein $a b-$ sent). Both diets contained the following ingredients: sugar (11.0 g), agar-agar (2.0 g), citric acid (1.0 g) e nipagin (1.0 g).

The following general methodology was used to measure the parameters mating success, copula duration and number of copulations. First, all specimens were separated according to their sex 24 hours after emergence and were maintained isolated from each other; males and females were fed either the $\mathrm{P} / \mathrm{P}$ or the $\mathrm{P} / \mathrm{A}$ diet during the first four days after emergence, which corresponds to the period of sexual maturation. Second, male individuals from each group were marked with non-toxic green or blue paint (Guache). On each replicate, group colors were alternated, as flies of the family Tephritidae have thoracic and wing marks that may have signaling function (Burk 1981, Sivinski et al. 2001).

Observations on mating behavior were conducted during six consecutive days, from 7:00 am to $3: 00 \mathrm{pm}$. According to our personal observations, six days corresponds to the maximum period of time for the first set of copulations to happen in this population. During this period, individuals were fed water saturated with sugar ad libitum. In the end of each daily observation (7:00 am - 3:00 pm), males and females were separated and placed in different cages containing their original diets. The cages were cleaned periodically to avoid ingestion of proteins from excrements and dead individuals. The following controlled conditions were maintained throughout the experiments: $25^{\circ} \mathrm{C}$ temperature, $70 \%$ relative humidity and photoperiod of 12 hours.

In order to evaluate mating success, eight males (four from each group) were placed in a plastic cage $(16 \times 11 \times 10 \mathrm{~cm})$ together with four female virgins of either group. As soon as mating was spotted, the mating couple was carefully placed into a test tube until the end of the copulation. Couples were not reintroduced into their original cages. A total of 16 replicates (cage = replicate unit), eight for each female group, were conducted.

Copula duration was recorded for all mating couples observed in the mating success experiment. In order to ensure that manipulation of specimens did not interfere with the results, however, only copulations of 15 minutes or more were considered. For each group of males tested, 25 copulations were evaluated. 
Two tests were conducted in order to evaluate the number of copulations per male. The first test ("A") consisted of exposing a male of the $\mathrm{P} / \mathrm{P}$ or the $\mathrm{P} / \mathrm{A}$ group to four female virgins (four days old) of the $\mathrm{P} / \mathrm{P}$ group. The second test (" $\mathrm{B}$ ") consisted of exposing a male of the $\mathrm{P} / \mathrm{P}$ or the $\mathrm{P} / \mathrm{A}$ group to four female virgins of the $\mathrm{P} / \mathrm{A}$ group. Mating couples were carefully placed into a test tube as soon as they were spotted, where they were kept until the end of the copulation. The male was then transferred to another cage containing four new female virgins, with conditions as before. A total of 19 males exposed to females on a $\mathrm{P} / \mathrm{P}$ diet, and a total of 15 males exposed to females on a P/A diet were evaluated.

We used the non-parametric Mann-Whitney test to evaluate the results obtained for number of copulations and mating success; the unpaired t test (with the Welch correction when necessary) for results of copula duration, the KolmogorovSmirnov test to access whether the data fit a normal distribution, and the Bartlett test to ascertain the homoscedasticity of the data distribution. Statistical tests were performed with the help of the program GraphPad InStat_version 3.00, with $\alpha=$ 0.05. Bonferoni correction was used whenever necessary.

\section{RESULTS}

The results for the three parameters evaluated, i.e. mating success, copula duration and copulation numbers are presented in table II. With respect to the rate of mating success, males of both groups, $\mathrm{P} / \mathrm{P}$ and $\mathrm{P} / \mathrm{A}$, had statistically similar performances, regardless of female diet. The copula duration was also statistically similar for both groups of males. With respect to the number of copulations, on the other hand, males of the $\mathrm{P} / \mathrm{P}$ group copulated more often with females of the $\mathrm{P} / \mathrm{A}$ group when compared with males of the P/A group. This tendency was not observed when males of either group were exposed to females of the $\mathrm{P} / \mathrm{P}$ group.

\section{DISCUSSION}

Previous studies using wild lineages of $C$. capitata have shown that ingestion of proteins in the adult phase enhances various aspects of male sexual behavior, as for example participation in leks, pheromone production, rate of copulation, and rate of sperm transfer (Yuval et al. 1998, KASPI et al. 2000, YUVAL et al. 2007). Contrasting results have been found when laboratory lineages are used, however (see Tab. I). For example, PAPAdOPOUlos et al. (1998) showed that wild adult males fed a protein-rich diet mature earlier and exude pheromones more frequently with respect to males deprived of protein, a result not confirmed in experiments using laboratory lineages. Furthermore, SHelly et al. (2002) were unable to verify the influence of protein ingestion on pheromone production in a laboratory population, a result that contrasts with that of KASPI \& Yuval (2000), who studied sterile males of a laboratory lineage.

The results obtained in this study do not corroborate previous findings that laboratory males fed a protein rich diet are more likely to copulate than males fed a protein-poor diet (Blay \& Yuval 1997, Kaspi \& Yuval 2000, Shelly et al. 2002). Other previous studies have also failed to demonstrate the effects of diet on the competitive abilities of laboratory males, either with each other or with wild males (SHelly \& KenNelly 2002, SHelly \& McInnis. 2003, Shelly et al. 2006). According to Yuval et al. (2007), conflicting results from various studies reflect diverse methodologies, different parameters being evaluated and the different lineages used.

Another important fact to be noted in previous studies is that the diet given to the flies tested during the larval phase is seldom specified. The flies used in our experiments were fed a high protein diet. Consequently, the lack of observed effects of protein deprivation on the sexual behavior of adult males could be explained by the fact that protein reserves carried over from the larval phase can be utilized by the young adult, as demonstrated for other insects (BogGs 1981, KarLsson 1995). To a certain extent, protein and fat reserves in the beginning of the pupation period have been shown to correlate positively with the amount of yeast offered through the larval period (NESTEL \& Nemny-Lavy 2008); when in excess, however, protein gets deposited in the exocuticle of the pupa, becoming unavailable to the adult (NesTel et al. 2004). Further corroboration of the hypothesis that larval diet affects adult characteristics is the study of KAspr et al. (2002), which demonstrates that a rich diet during the larval phase results in adult males that mature earlier. Additionally, a study by Maria do Carmo Plácido-Silva, Insti-

Table II. Influence of adult protein ingestion on mating success, copula duration, and number of copulations of males of C. capitata exposed to females fed protein-rich and no-protein diets. Either the median (mating success and number of copulations/male - range of variation indicated between brackets) or the mean \pm standard deviation (copula duration) are represented. (P/P) Protein present in diet, $(\mathrm{P} / \mathrm{A})$ protein absent in diet. The pair (in column) with an asterisk was the only to present statistical difference.

\begin{tabular}{|c|c|c|c|c|c|c|}
\hline & \multicolumn{6}{|c|}{ Females } \\
\hline & \multicolumn{2}{|c|}{$\begin{array}{l}\text { Mating success (number of males } \\
\text { chosen) Mann-Whitney test }\end{array}$} & \multicolumn{2}{|c|}{$\begin{array}{l}\text { Copula duration (minutes) Unpaired T-test } \\
\text { (with Welch correction) } \\
\end{array}$} & \multicolumn{2}{|c|}{$\begin{array}{c}\text { Number of copulations/male } \\
\text { Mann-Whitney test }\end{array}$} \\
\hline & $\mathrm{P} / \mathrm{P}$ & $\mathrm{P} / \mathrm{A}$ & $\mathrm{P} / \mathrm{P}$ & $\mathrm{P} / \mathrm{A}$ & $\mathrm{P} / \mathrm{P}$ & $\mathrm{P} / \mathrm{A}$ \\
\hline Males P/P & $1.5(0.0-3.0)$ & $2.0(1.0-3.0)$ & $156.7 \pm 67.3$ & $145.9 \pm 26.8$ & $1.5(1.0-4.0)$ & $5.0(3.0-8.0)^{\star}$ \\
\hline Males P/A & $2.5(1.0-3.0)$ & $2.0(1.0-3.0)$ & $163.6 \pm 25.4$ & $159.1 \pm 40.1$ & $4.0(1.0-7.0)$ & $3.0(2.0-7.0)^{\star}$ \\
\hline P-value & 0.1526 & 0.5573 & 0.7239 & 0.3701 & 0.0928 & 0.0493 \\
\hline
\end{tabular}


tuto de Biologia, Universidade Federal da Bahia (unpublished data), showed that males fed a protein-rich diet during the larval phase and subsequently fed a low-protein diet in the beginning of the adult phase had higher rate of mating success when compared with males that received a protein-rich diet as larvae and adults. In contrast, males fed a protein-poor diet in the larval phase did not differ with respect to mating success in the adult phase, regardless of adult diet. These results highlight the importance of the larval diet on adult sexual behavior, and may in part explain the general consensus on the role of proteins in the adult phase of wild males. In fact, fruits (the natural diet of wild flies) are poorer in protein content when compared with yeast fed to populations in the laboratory. Consequently, adults from wild populations emerge with a shorter protein reserve and may therefore need a diet richer in proteins when compared with adults reared in the laboratory. A similar situation has been observed on the subject of female egg production in wild and laboratory populations of $C$. capitata. According to Yuval et al. (2007), wild females are anautogenous (require proteins in the adult life in order to produce eggs), whereas laboratory reared females are autogenous (do not require proteins in the adult life in order to produce eggs, even though protein consumption may increase egg production) with respect to proteins (CANGussu \& Zucoloto 1993). Most likely, the differing protein requirements between wild and laboratory lineages are due to the fact that the latter are adapted to the high protein contents of artificial diets which may exert selective pressure during the colonization of a laboratory population, as discussed by Meats et al. (2004).

As stated in the results section, copula duration resulted statistically independent from adult diet. Large standard deviations were also observed around the mean duration of copula in both groups. Similar variability in copulation duration was obtained in other studies. For example, Eberhard (1999) showed that copulation (counting only the events that led to storage of sperm in the spermatheca) lasted from 90 to 170 minutes within and across different lineages of fruit flies. Additionally, PARANHos et al. (2006) found that wild flies copulate for longer periods of time when compared with flies from laboratory lineages. Also, Field \& Yuval (1999) showed that males and females with protein deficiency copulated for longer periods of time, despite individual variations in copulation length. The latter results were not corroborated by our data, which show no correlation between copula duration and diet. SHelly \& Kennely (2002) also failed to find a correlation between adult diet and copula duration. Prabhu et al. (2008), on the other hand, showed that males of another species, Bactrocera tryoni (Froggatt, 1897), copulated for longer periods of time when fed protein-rich diet, as opposed to males deprived of proteins. In conclusion, the various studies on the effects of diet on the reproductive behavior of fruit flies have proved difficult to determine the roles of age, nutrition and other factors on copula duration (Field et al. 1999).
Reproductive success in males and females is subject to different selective pressures, causing a conflict between the sexes (ANderson 1994, BirkHeAd \& PARKER 1997). A reproductively successful male copulates with a large number of females, whereas a female must be able to choose the best available mate in order to guarantee her reproductive success. Research on $C$. capitata has focused on female receptivity, i.e. the factors that contribute to her repeated copulations, as for example the duration of the first copula (SAUL et al. 1988, Mossinson \& YUVAL 2003), nutritional status of the male (BLAY \& Yuval 1997, SHeLLY \& Kennelly 2002), and male or female lineages (Shelly \& Kennelly 2002, Mossinson \& Yuval 2003, Vera et al. 2002, 2003). The parameters that interfere with the number of copulations a male can engage in, on the other hand, are seldom subject to research, despite their special relevance to control programs using the SIT. Indeed, the male potential to inseminate a large number of females is very important to the success of this technique. According to our study, males of the $\mathrm{P} / \mathrm{P}$ group, when exposed to females of the P/A group, copulated more often than males of the P/A group exposed to the same group of females. When males of both groups were exposed to females of the $\mathrm{P} / \mathrm{P}$ group, however, no significant differences in mating frequency was observed between groups. These results suggest that the number of times a male can mate on a given period of time is not dependent on his diet during the adult phase, but on the adult diet of the females he encounters. It appears as if the diet given to the female during her adult phase influences her ability to select her mates. Consequently, females deprived of protein accept well-nurtured males more often, either because these males show more vigorous displays or because the pheromones quality, or both. The females subjected to a protein rich diet, on the other hand, do not show this preference. The reason for this difference in female behavior needs to be investigated by studies that take the nutritional levels of both sexes into consideration.

\section{ACKNOWLEDGEMENTS}

We thank Fundação de Amparo a Pesquisa do Estado da Bahia (FAPESB) for the finantial support granted to the second author (process 1431040013029).

\section{LITERATURE CITED}

Anderson, M. 1994. Sexual Selection. Princeton, New Jersey, 599 p.

AritA, L.H. \& K.Y. Kaneshiro. 1989. Sexual selection and lek behavior in the Mediterranean fruit fly, Ceratitis capitata. Pacific Science 43: 135-143.

BlaY, S. \& B. Yuval. 1997. Nutritional correlates of reproductive success of male Mediterranean fruit flies (Diptera: Tephritidae). Animal Behavior 54: 59-66.

BirKheAD, T.R. \& G.A. PARKER. 1997. Sperm Competition and Mating Systems, p. 121-148. In: Wiley-BlackWell (Ed.). Behavioural 
ecology: an evolutionary approach. Cambridge, Kingdom at the University Press, 456p.

Boggs, C.L. 1981. Nutritional and life-history determinants of resource allocation in holometabolous insect. America Naturalist 117: 692-709.

BuRk, T. 1981. Signaling and sex in acalyptrate flies. Florida Entomologist 64: 30-43.

Cangussu, J.A. \& F.S. Zucoloto. 1993. Influence of partial malnutrition on egg production by Ceratitis capitata (Diptera, Tephritidae). Revista Brasileira de Biologia 53 (2): 155-158.

Cangussu, J.A. \& F.S. Zucoloto. 1995. Self-selection and perception threshold in adult females of Ceratitis capitata. Journal of Insect Physiology 41: 223-227.

Cangussu, J.A. \& F.S. Zucoloto. 1997. Effect of protein sources on fecundity, food acceptance and sexual choice by Ceratitis capitata (Diptera: Tephritidae). Revista Brasileira de Biologia 57 (4): 611-618.

Carvalho, R.S.; A.S. Nascimento \& W.J. Matrangolo. 1998. Metodologia de criação do parasitóide exótico Diachasmimorpha longicaudata (Hymenoptera: Braconidae), visando estudos em laboratório e em campo. Circular Técnica Embrapa, \# 30, 16p.

Churchill-Stanland C.; R. Stanland; T.Y. Wong; N. Tanaka; D.O. McINNIS \& R.V. Dowell. 1986. Size as a factor in the mating propensity of the Mediterranean Fruit flies, Ceratitis capitata (Diptera, Tephritidae), in the laboratory. Journal of Economic Entomology 79: 614-619.

Eberhard, W.G. 1999. Sexual behavior and sexual selection in the medfly, Ceratitis capitata, p. 459-489. In: M. Aluja \& A. Norrbom (Ed.). Fruit Flies (Tephritidae): Phylogeny and Evolution of Behavior. Boca Raton, CRC Press. 963p.

Féron, M. 1962. L'instinct de reproduction chez la mouche Mediterranéenne des fruits (Ceratitis capitata Wiedemann) (Diptera, Tephritidae). Comportement sexuel. Comportement de ponte. Revue de Pathologie Végétale et d'Entomologie Agricole de France 41: 1-129.

Field, S.A. \& B. Yuval. 1999. Nutritional status affects copula duration in the Mediterranean fruit fly, Ceratitis capitata (Insecta, Tephritidae). Ethology, Ecology and Evolution 11 (1): 61-70.

Field, S.A.; P.W. TaYlor \& B.Yuval. 1999. Sources of variability in copula duration of Mediterranean Fruit Flies. Entomologia Experimentalis et Applicata 92: 271-276.

Hendrichs, J. \& M.A. Hendrichs. 1990. Mediterranean fruit fly (Diptera: Tephritidae) in nature: localization and diel pattern of feeding and other activities on fruiting and nonfruiting hosts and nonhosts. Annals of the Entomological Society of America 83: 632-641.

KARLSSON, B. 1995. Resource allocation and mating systems in butterflies. Evolution 49: 955-961.

KaSPI, R. \& B. YuvaL. 2000. Post-teneral protein feeding improves sexual competitiveness but reduces longevity of mass reared sterile male Mediterranean fruit flies. Annals of the Entomo- logical Society of America 93: 949-955.

KasPi, R.; P.W. TAYlor \& B. Yuval. 2000. Diet and size influence sexual advertisement and copulatory success of males in Mediterranean fruit fly leks. Ecological Entomology 25: 279284.

Kaspi, R.; S. Mossinson; T. Drezner; B. Kamensky \& B. Yuval. 2002. Effects of larval diet on development rates and reproductive maturation of male and female Mediterranean fruit flies. Physiological Entomology 27: 29-38.

KNIPLING, E.F. 1955. Possibilities of insect control or eradication through the use of sexual sterile males. Journal of Economic Entomology 48: 459-462.

Malavasi, A.; R.A. Zucchi \& R.L. Sugayama. 2000. Biogeografia, p. 93-98. In: A. Malavasi \& R.A. Zucchi (Eds). Moscas das frutas de importância econômica no Brasil: conhecimento básico e aplicado. Ribeirão Preto, Holos Editora, 327p.

MaOr, M.; B. Kamensky; S. Shloush \& B. Yuval. 2004. Effects of post-teneral diet on foraging sucess of sterile male Mediterranean fruit flies. Entomologia Experimentalis et Applicata. 110: $225-230$.

MeATs A.; H.M. Holmes \& G.L. Kelly. 2004. Laboratory adaptation of Bactrocera tryoni (Diptera: Tephritidae) decreases mating age and increases protein consumption and number of eggs produced per milligram of protein. Bulletin of Entomological Research 94: 517-524.

Mossinson, S. \& B. Yuval. 2003. Regulation of sexual receptivity of female Mediterranean fruit flies: old hypotheses revisited and a new synthesis proposed. Journal of Insect Physiology 49: 561-567.

Nestel, D. \& E. Nemny-Lavy. 2008. Nutrient balance in medfly, Ceratitis capitata, larval diets affects the ability of the developing insect to incorporate lipid and protein reserves. Entomologia Experimentalis et Applicata 126: 53-60.

Nestel, D.; E. Nemny-Lavy \& C.L. Chang. 2004. Lipid and protein loads in pupating larvae and emerging adult as affected by the composition of a Mediterranean fruit fly (Ceratitis capitata) meridic larval diets. Archives of Insect Biochemistry and Physiology 56: 97-109.

Norry, F.M.; G.E. Calcagno; M.T. Vera; F. Manso \& J.C. Vilardi. 1999. Sexual selection on morphology independent of malemale competition in the Mediterranean fruit fly (Diptera: Tephritidae). Annals of the Entomological Society of America 92 (4): 571-577.

Orozco, D. \& R.O. Lopez. 1993. Mating competiveness of wild and laboratory mass-reared medflies: effect of male size, $p$. 185-188. In: M Aluja \& P Liedo (Ed.). Fruit flies: biology and management. New York, Springer, 492p.

Papadopoulos, N.T.; B.I. Katsoyannos; N.A. Kouloussis, A.P. ECONOMOPOUlos \& J.R. CARrey. 1998. Effect of adult age, food, and time of day on sexual calling incidence of wild and massreared Ceratitis capitata males. Entomologia Experimentalis et Applicata 89: 175-182.

Paranhos, B.J.; D. McInnis; K. Uramoto; I. Damasceno; N. Gonçal- 
ves;R.M. Alves; M.L. Costa; J. Walder; A. Malavasi \& A. NasciMENTO. 2006. Sterile medfly males of the $t S L$ Vienna 8 genetic sexing strain display improved mating performance with ginger root oil. In: Proceedings of the $7^{\text {th }}$ International Symposium on Fruit Flies of Economic Importance. Salvador, 10-15 September 2006, p. 313-318.

Plácido-Silva, M.C.; F.S. Zucoloto \& I.S. Joachim-Bravo. 2005. Influence of protein on feeding behavior of Ceratitis capitata Wiedemann (Diptera: Tephritidae): comparison between immature males and females. Neotropical Entomology 34 (4): 539-545.

Plácido-Silva; M.C.; A.M. Silva Neto; F.S. Zucoloto \& I.S. JoachimBravo. 2006. Effects of Different Protein Concentrations on Longevity and Feeding Behavior of Two Adult Populations of Ceratitis capitata Wiedemann (Diptera: Tephritidae). Neotropical Entomology 35 (6): 747-752.

Prabhu, V.; D. Perez-Staples \& P.W. Taylor. 2008. Protein: carbohydrate ratios promoting sexual activity and longevity of male Queensland fruit. Journal of Application Entomology 132: 575-582.

Prokopy, R.J. \& J. Hendrichs. 1979. Mating behavior of Ceratitis capitata on a field-cage host tree. Annals of the Entomological Society of America 72: 642-648.

Rodriguero, M.S.; J.C. Vilardi; M.T. Vera; J.P. Cayol \& E.Rial. 2002. Morphometric traits and sexual selection in medfly (Diptera: Tephritidae) under field cage conditions. Florida Entomologist 85: 143-149.

SAUL, S.H.; S.Y.T. TAM \& D.O. McInNIS. 1988. Relationship between sperm competition and copulation duration in the Mediterranean fruit fly (Diptera: Tephritidae). Annals of the Entomological Society of America: 498-502.

SHelly, T.E. \& S.S. KenNelly. 2002. Influence of male diet on male mating success and longevity and female remating in the Mediterranean fruit fly (Diptera: Tephritidae) under laboratory conditions. Florida Entomologist 85: 572-579.

Shelly, T.E. \& D.O. McInNIs. 2003. Influence of adult diet on the mating success and survival of male Mediterranean fruit flies (Diptera: Tephritidae) from two mass-rearing strains on fieldcaged host trees. Florida Entomologist 86 (3): 340-344.

Shelly, T.E.; S.S. Kennelly \& D.O. McInnis. 2002. Effect of adult diet on signaling activity, mate attraction, and mating success in male Mediterranean fruit flies (Diptera: Tephritidae). Florida Entomologist 85: 150-155.

Shelly, T.E.; J. Edu \& E. PAhio. 2006. Dietary protein and mating competitiveness of sterile males of the Mediterranean fruit fly (Diptera: Tephritidae): measurements of induced egg sterility in large field enclosures. Florida Entomologist 89 (2): 277-278.

Sivinski, J.; M. Aluja; G. Dodson; A. Freidberg; D. Headrick; K. Kaneshiro \& P. Landolf. 2001. Topics in the evolution of sexual behavior in the Tephritidae, p. 751-792. In: M. AluJA \& A. Norrbom (Eds). Fruit flies (Tephritidae): phylogeny and evolution of behavior. Boca Raton, CRC Press, 963p.

Slansky JR, F. \& M.R. Scriber. 1985. Food consumption and utilization, p. 87-151. In: S.A. Kerkut \& J.F. Gilbert (Eds). Comprehensive Insect Physiology, Biochemistry and Pharmacology. Oxford, Pergamon Press, 743p.

TAYlor, P.W. \& B. Yuval. 1999. Postcopulatory sexual selection in Mediterranean fruit flies: advantages for large and proteinfed males. Animal Behavior 58: 247-254.

Taylor, P.W; R. Kaspi \& B. Yuval. 2000. Copula duration and sperm storage in Mediterranean fruit flies from a wild population. Physiological Entomology 25: 94-99.

Vera, M.T.; R. Wood; J.L. Cladera \& A.Gilburn. 2002. Remating frequency in the Mediterranean fruit fly (Diptera: Tephritidae) under laboratory conditions. Florida Entomology 85: 156-164.

Vera, M.T.; J.L. Cladera; G. Calcagno; J.C. Vilardi, D.O. McInnis \& Field Working Group. 2003. Remating of wild Ceratitis capitata (Diptera: Tephritidae) females in field cages. Annals of the Entomological Society of America 96 (4): 563-570.

WARBURG, M.S. \& B. Yuval. 1996. Effects of energetic reserves on behavioral patterns of Mediterranean fruit flies. Oecologia 112: 314-319.

Whittier, T.S.; K.Y. Kaneshiro \& L.D. Prescot. 1992. Mating behavior of Mediterranean fruit flies (Diptera: Tephritidae) in a natural environment. Annals of the Entomological Society of America 85: 214-218.

Whittier, T.S.; F.Y. NAN; T.E. Shelly \& K.Y. Kaneshiro. 1994. Male courtship success and female discrimination in the Mediterranean fruit fly (Diptera: Tephritidae). Journal of Insect Behavior 7: 159-170.

Yuval, B.; R. Kaspi; S. Shloush \& M.V. Warburg. 1998. Nutritional reserves regulate male participation in Mediterranean fruit fly leks. Ecological Entomology 23: 211-215.

Yuval, B.; K. Levy; R. KasPi; P. TAYlor; \& T. Shelly. 2007. Breakfast of champions or kiss of death? Survival and sexual performance of protein-fed, sterile Mediterranean fruit flies (Diptera: Tephritidae). Florida Entomologist 90 (1): 115-122.

Zucoloto, F.S. 1987. Feeding habits of Ceratitis capitata: Can larvae recognize a nutritional effective diet? Journal of Insect Physiology 33: 349-353.

Submitted: 23.XII.2008; Accepted: 09.IX.2009.

Editorial responsibility: Pedro Gnaspini Netto 